\title{
Occupational exposures and pancreatic cancer: a meta-analysis
}

I Anneli Ojajärvi, Timo J Partanen, Anders Ahlbom, Paolo Boffetta, Timo Hakulinen, Nadia Jourenkova, Timo P Kauppinen, Manolis Kogevinas, Miquel Porta, Harri U Vainio, Elisabete Weiderpass, Catharina $\mathrm{H}$ Wesseling

\begin{abstract}
Department of Epidemiology and Biostatistics, Finnish Institute of Occupational Health, Topeliuksenk 41A, 00250 Helsinki, Finland I A Ojajärvi

T J Partanen T P Kauppinen
\end{abstract}

Institute of Environmental Medicine, Karolinska Institutet, Stockholm, Sweden

A Ahlbom

C H Wesseling

Institute of Medical Epidemiology, Karolinska Institutet, Stockholm, Sweden E Weiderpass

Unit of Environmental Cancer Epidemiology, International Agency for Research on Cancer, Lyon, France P Boffetta

Unit of

Chemoprevention, International Agency for Research on Cancer, Lyon, France $\mathrm{H}$ U Vainio

Finnish Cancer Registry, Helsinki, Finland

T Hakulinen

Institut National de la Santé et de la Reserche Médicale, Villejuif, France

N Jourenkova

Institut Municipal d'Investigacio Medica, Barcelona, Spain

M Kogevinas

M Porta

Universidad Nacional, Heredia, Costa Rica C H Wesseling

Correspondence to: Dr Anneli Ojajärvi aoja@occuphealth.fi

Accepted 30 December 1999

\begin{abstract}
Objectives-Consolidation of epidemiological data on pancreatic cancer and worksite exposures.

Methods-Publications during 1969-98 were surveyed. Studies without verified exposures were excluded. Meta-analyses were conducted on data from 92 studies covering 161 populations, with results for 23 agents or groups of agents. With a standard format, five epidemiologists extracted risk estimates and variables of the structure and quality of each study. The extracted data were centrally checked. Random meta-models were applied.
\end{abstract}

Results-Based on 20 populations, exposure to chlorinated hydrocarbon (CHC) solvents and related compounds was associated with a meta-risk ratio (MRR) of 1.4 (95\% confidence interval $(95 \% \mathrm{CI}) 1.0$ to 1.8). Nickel and nickel compounds were considered in four populations $(1.9 ; 1.2$ to 3.2). Excesses were found also for chromium and chromium compounds $(1.4 ; 0.9$ to 2.3), polycyclic aromatic hydrocarbons (PAHs) (1.5; 0.9 to 2.5 ), organochlorine insecticides $(1.5 ; 0.6$ to 3.7$)$, silica dust $(1.4 ; 0.9$ to 2.0$)$, and aliphatic and alicyclic hydrocarbon solvents $(1.3 ; 0.8$ to 2.8$)$. Evidence on pancreatic carcinogenicity was weak or non-positive for the following agents: acrylonitrile $(1.1 ; 0.0$ to 6.2$)$; arsenic $(1.0 ; 0.6$ to 1.5$)$; asbestos $(1.1 ; 0.9$ to 1.5$)$; diesel engine exhaust $(1.0 ; 0.9$ to $1.3)$; electromagnetic fields $(1.1 ; 0.8$ to $1.4)$; formaldehyde $(0.8 ; 0.5$ to 1.0$)$; flour dust $(1.1 ; 0.3$ to 3.2$)$; cadmium and cadmium compounds $(0.7 ; 0.4$ to 1.4$)$; gasoline $(1.0 ; 0.8$ to 1.2$)$; herbicides $(1.0$; 0.8 to 1.3$)$; iron and iron compounds (1.3; 0.7 to 2.5$)$; lead and lead compounds (1.1; 0.8 to 1.5$)$; man-made vitreous fibres $(1.0$; 0.6 to 1.6$)$; oil mist $(0.9 ; 0.8$ to 1.0$)$; and wood dust $(1.1 ; 0.9$ to 2.5$)$. The occupational aetiological fraction of pancreatic cancer was estimated at $12 \%$. In a subpopulation exposed to $\mathrm{CHC}$ solvents and related compounds, it was $29 \%$; to chromium and chromium compounds, $23 \%$; to nickel and nickel compounds, $47 \%$; to insecticides, $33 \%$; and to PAHs, $33 \%$.

Conclusion-Occupational exposures may increase risk of pancreatic cancer. High quality studies are called for on interactions between occupational, environmental, and lifestyle factors as well as interactions between genes and the environment.

(Occup Environ Med 2000;57:316-324)

Keywords: pancreatic cancer; occupational exposure; meta-analysis

Some 180000 pancreatic cancers are registered annually in the world. It is highly and rapidly fatal and represents the fifth leading cause of deaths from cancer in industrialised countries and is $50 \%-100 \%$ more common in men than in women. It is not consistently associated with socioeconomic status within national populations, although there is a tendency toward higher age adjusted risk in richer than poorer countries. ${ }^{1-3}$ Incidence has risen in industrialised countries since the 1960s and subsequently levelled off in several populations. $^{4}$

The causes of pancreatic cancer are mostly unknown. Tobacco smoking is the single established common cause. The proportion of cases attributable to smoking has been estimated at $5 \%-50 \%$, depending on the population. ${ }^{3}$ Epidemiology of pancreatic cancer has suffered from bias due to high misclassification rate, notably prominent when case definition has been based only on death certificates. This has resulted in inconsistencies in the results on the aetiological role of environmental and occupational determinants of pancreatic cancer. ${ }^{3-6}$

We identified published epidemiological studies about pancreatic cancer and job titles, industrial branches, and occupational exposures, and conducted a meta-analysis of the role of 23 chemical or physical agents present in the working environment that affect the aetiology of pancreatic cancer.

Materials and methods

The literature search covered the Medline, Toxline, and Cancerlit databases for the period 1969 to May 1998, with the following search conditions:

(1) (occupational OR agriculture) AND neoplasms AND morbidity

(2) (occupational OR agriculture) AND neoplasms AND mortality NOT morbidity

(3) (occupational OR agriculture) AND neoplasms AND incidence NOT mortality NOT morbidity

(4) (pancreatic OR digestive) AND occupational

(5) (pancreatic OR digestive) AND case AND (control OR referent) 
The search was accompanied by a scan of the lists of reference of the identified studies. In all, 1902 studies were identified. A total of 365 studies remained after exclusion of studies that did not report on pancreatic cancer; that did not represent the most recent update; that reported insufficient data for the meta-analysis; that did not report data for any job or occupational agent; that did not report original results (reviews); that reported on part of a larger population reported elsewhere; and that reported on job categories or agent categories too broad or outside our list of job titles and agents. The agents were based on the FINJEM job exposure matrix. ${ }^{7}$ The list of job titles covered 150 entries in the Finnish social status categories 3, 4, and 5. Data for categories 1 and 2 represented the highest social categories and were excluded because the relevant occupational chemical and physical exposures were minimal or non-existent. The chemical and physical agents considered were the following 23 agents or groups of agents: aliphatic and alicyclic hydrocarbon solvents; aromatic hydrocarbon solvents (excluding aromatic amines); arsenic; asbestos; cadmium and cadmium compounds; chlorinated hydrocarbon $(\mathrm{CHC})$ solvents and related compounds (excluding organochlorine insecticides); chromium and chromium compounds; diesel engine exhaust; electromagnetic fields, flour dust, formaldehyde, fungicides, gasoline, herbicides, insecticides, iron and iron compounds; lead and lead compounds; man made vitreous fibres; nickel and nickel compounds; oil mist (including machining fluid and cutting fluid); polycyclic aromatic hydrocarbons (PAH); silica dust; and wood dust.

The studies were divided into (a) agent specific studies with direct risk estimates for one or several of the 23 agents, or for job titles with verified exposure(s) to the agent(s), and (b) job specific studies without risk estimates for any of the selected agents but instead for one or more of the 150 job categories without verified exposure(s) to the agent(s). This report is based on the data set from agent specific studies only (92 studies presenting data for 161 different exposed populations). ${ }^{8-99}$

Standardised data extraction forms (available from the corresponding author) covered characteristics of the study (publication year, country, study type, case definition, source of cases, reference population, selection of control subjects, follow up period, loss to follow up, response rates, sources of exposure or job data, time reference for exposure or job; risk measure, cohort admission, lag periods, exposure-response, job title coding applied), risk estimates, latency periods, and numbers of exposed cases.

Five epidemiologists (AO, TP, NJ, EW, CW) read the reports and extracted the necessary data, using predefined rules. The main principles of extraction were to extract:

- Relevant, unbiased estimates of relative risk

- Measures of relative risks associated with specific exposures and job titles
- The most unbiased estimate if there is a choice and choose:

- Estimates adjusted for at least known risk factors for pancreatic cancer (age, sex, tobacco smoking), if there was a choice

- Social class adjusted risk ratios over those unadjusted for social class

- Risk estimate nearest to 20 y latency period, if there is a choice.

The extracted data were then centrally checked for consistency (AO, TP) and finally entered into a database and checked for correctness.

We recovered missing 95\% CIs with Byar's approximation $^{100}$ in cohort studies, and with variance of log odds ratio in case-control studies.

Simple random effects models ${ }^{101}$ were applied in estimating the meta-risk ratios (MRR). Fixed effects models were used only on occasion for comparison with results from random effects models. Standard errors of log of

Table 1 Characterisation of the 92 agent specific studies

\begin{tabular}{|c|c|}
\hline & $\begin{array}{l}\text { Populations } \\
\text { (n) }\end{array}$ \\
\hline \multicolumn{2}{|l|}{ Study type: } \\
\hline $\begin{array}{l}\text { Administrative (linkage of administrative } \\
\text { records or PMR/PCMR/MOR studies) }\end{array}$ & 23 \\
\hline Industrial cohort & 88 \\
\hline Industry based (nested) case-control study & 7 \\
\hline $\begin{array}{l}\text { Population or hospital based case-control } \\
\text { study }\end{array}$ & 43 \\
\hline \multicolumn{2}{|l|}{ Cases: } \\
\hline Exocrine pancreatic cancers only & 32 \\
\hline All pancreatic cancers & 127 \\
\hline Unspecified & 2 \\
\hline \multicolumn{2}{|l|}{ Diagnosis of cases: } \\
\hline Histological & 47 \\
\hline Other (clinical: radiology, necropsy, etc) & 2 \\
\hline Mortality files & 96 \\
\hline Mixed & 9 \\
\hline Unknown & 7 \\
\hline \multicolumn{2}{|l|}{ Ascertainment of cases: } \\
\hline Mortality files & 98 \\
\hline Cancer registry files & 40 \\
\hline Hospital records & 21 \\
\hline Mixed & 1 \\
\hline Unspecified & 1 \\
\hline \multicolumn{2}{|l|}{ Sex: } \\
\hline Men & 112 \\
\hline Women & 8 \\
\hline Both men and women or unspecified & 41 \\
\hline \multicolumn{2}{|l|}{ Risk measure: } \\
\hline SMR (standardised mortality ratio) & 68 \\
\hline SIR (standardised incidence ratio) & 17 \\
\hline PMR (proportional mortality ratio) & 18 \\
\hline MOR (mortality odds ratio) & 1 \\
\hline HR (hazard ratio) & 3 \\
\hline OR (odds ratio) & 50 \\
\hline $\mathrm{RR}\left(\right.$ (risk ratio) ${ }^{\star}$ & 4 \\
\hline \multicolumn{2}{|l|}{ Source of exposure data: } \\
\hline Industrial hygiene measurements & 4 \\
\hline Job exposure matrix & 15 \\
\hline Expert assessment & 25 \\
\hline Job titlest & 57 \\
\hline Other $\neq$ & 19 \\
\hline Mixed & 37 \\
\hline Unknown & 4 \\
\hline \multicolumn{2}{|l|}{ Time reference of exposure: } \\
\hline Last or around diagnosis & 17 \\
\hline Earlier cross section & 9 \\
\hline Lifetime longitudinal & 47 \\
\hline Less than lifetime longitudinal & 80 \\
\hline Other & 1 \\
\hline Unknown & 7 \\
\hline Total & 161 \\
\hline
\end{tabular}

‡Employment duration, biological monitoring, employer record, registry of chemicals, self reporting. 
risk ratios (RRs), when not given, were recovered as the log of the ratio of upper and lower $95 \%$ CIs divided by 3.92. A test of the heterogeneity was performed as a $\chi^{2}$ test with degrees of freedom equal to one less than the number of populations. The public domain software package computer programs for epidemiologic analysis (PEPI; http://www.usdinc.com/pepi.htlm), version 3.0, and the statistical software package Stata release 5 were used. $^{102}$

Population aetiological fractions were estimated as $P E F=p-p / M R R$, and aetiological fractions among the exposed groups as $E E F=1-1 / M R R$ for each agent where excesses were observed. The proportion of pancreatic cancer cases who were exposed (p), was calculated as $\Sigma$ exposed cases $/ \Sigma$ all cases, summing over studies that provided the necessary numbers. The PEFs were based on MRRs from population based and hospital based case-control studies only, whereas the EEFs were based on MRRs from all except proportional studies. Aetiological fractions were not calculated for agents with no indication of increased risk.

The data were organised and analysed by populations rather than studies. This was because most studies considered more than one subpopulation defined by exposure. A total of 161 populations were covered in agent specific studies (table 1). Most (85) populations were from North America, closely followed by Western Europe (63). There were few populations from Central and Eastern Europe, Oceania, and none from Middle and South America, Asia, or Africa. The annual number of studies has been rising considerably during 1969-8 (two studies during 1969-79; 58 studies during 1980-9, and 101 studies during 1990-8).

Industrial cohort ( 88 populations) and casecontrol (50 populations) studies were the most common agent specific studies (table 1 ). The cases represented predominantly all pancreatic

Table 2 Populations (n), metarisk estimates (MRRs) (95\% CIs), ranges of point estimates and $p$ values for heterogeneity by occupational agents (proportional studies excluded: simple random effects models with no covariates)

\begin{tabular}{|c|c|c|c|c|c|}
\hline Agent & $n$ & $M R R$ & $95 \% C I$ & $\begin{array}{l}\text { Range of point } \\
\text { estimate }\end{array}$ & $p$ Value \\
\hline Aliphatic and alicyclic hydrocarbon solvents & 2 & 1.3 & 0.8 to 2.0 & $1.0-1.6$ & 0.09 \\
\hline Aromatic hydrocarbon solvents & 13 & 1.0 & 0.8 to 1.3 & $0.5-2.9$ & 0.2 \\
\hline Arsenic & 4 & 1.0 & 0.6 to 1.6 & $0.9-1.4$ & 0.9 \\
\hline Asbestos & 24 & 1.1 & 0.9 to 1.4 & $0.5-3.6$ & 0.004 \\
\hline Cadmium and cadmium compounds & 2 & 0.7 & 0.4 to 1.4 & $0.7-0.8$ & 0.9 \\
\hline $\begin{array}{l}\text { Chlorinated hydrocarbon solvents and } \\
\text { related compounds }\end{array}$ & 20 & 1.4 & 1.0 to 1.8 & $0.3-4.9$ & 0.05 \\
\hline Chromium and chromium compounds & 9 & 1.4 & 0.9 to 2.3 & $0.6-20$ & 0.2 \\
\hline Diesel engine exhaust & 7 & 1.0 & 0.9 to 1.2 & $0.5-1.4$ & 0.2 \\
\hline Electromagnetic fields & 5 & 1.1 & 0.8 to 1.4 & $0.6-2.4$ & 0.04 \\
\hline Flour dust & 1 & 1.1 & 0.3 to 3.2 & & \\
\hline Formaldehyde & 5 & 0.8 & 0.5 to 1.0 & $0.5-1.0$ & 0.3 \\
\hline Fungicides & 2 & 1.3 & 0.4 to 3.8 & $1.3-1.4$ & 0.9 \\
\hline Gasoline & 4 & 1.0 & 0.8 to 1.2 & $0.2-1.1$ & 0.5 \\
\hline Herbicides & 10 & 1.0 & 0.8 to 1.3 & $0.6-5.9$ & 0.3 \\
\hline Insecticides & 3 & 1.5 & 0.6 to 3.7 & $0.8-21.0$ & 0.1 \\
\hline Iron and iron compounds & 1 & 1.3 & 0.7 to 2.5 & & \\
\hline Lead and lead compounds & 4 & 1.1 & 0.8 to 1.5 & $1.0-1.4$ & 1.0 \\
\hline Man made vitreous fibres & 5 & 1.0 & 0.6 to 1.6 & $0.3-6.8$ & 0.03 \\
\hline Nickel and nickel compounds & 4 & 1.9 & 1.2 to 3.2 & $1.2-3.6$ & 0.9 \\
\hline Oil mist & 6 & 0.9 & 0.8 to 1.0 & $0.3-1.0$ & 0.5 \\
\hline Polycyclic aromatic hydrocarbons (PAHs) & 4 & 1.5 & 0.9 to 2.5 & $1.3-3.6$ & 0.8 \\
\hline Silica dust & 3 & 1.4 & 0.9 to 2.0 & $1.1-2.0$ & 0.2 \\
\hline Wood dust & 4 & 1.1 & 0.8 to 1.5 & $0.7-1.7$ & 0.3 \\
\hline
\end{tabular}

cancers, irrespective of type. As most studies considered mortality, the diagnosis was in most populations obtained from the death record. Less than $5 \%$ of the populations were women. Exposures were assessed in 57 populations through job titles; in 25 through expert assessments; in 15 through job exposure matrices (JEMs); and in 60 through other, mixed, or unexplained methods. Industrial hygiene measurements were explicitly applied in four populations only. Exposure assessment was longitudinal for 127 populations.

Reference populations in cohort studies represented predominantly national or other large populations (57 studies). Fewer studies (23) used local populations as the reference; even fewer (seven) used an internal reference. Follow up for case ascertainment began usually during 1940-79 (99 studies) and spanned in most studies a period of $\geqslant 10$ years (98 studies). Losses to follow up in agent specific cohort studies were minor or moderate $(<5 \%$ in 44 studies but unknown in 51 studies) but were more marked in job branch cohort studies. Agent specific cohorts were rather evenly distributed between entry cohorts, cross sectional cohorts, and mixed cohorts.

Case-control studies used variable periods of case ascertainment. Most agent specific casecontrol studies (44) used cancer or population controls. Response rates were $\leqslant 80 \%$ for the cases, and $\leqslant 90 \%$ in the controls. Sixteen studies did not report response rates.

\section{Results}

The aggregated results for the occupational agents are shown in table 2. Random effects models without covariates were used. Proportional studies (four) representing 18 populations, were excluded from most analyses because of poor quality. The study by Magnani et $a l,{ }^{62}$ although reported as a case-control study, used job and branch data as well as diagnoses of pancreatic cancer from death certificates only. We therefore treated it as a proportional mortality rate (PMR) study.

Significant excesses were found for nickel and nickel compounds (MRR $1.9 ; 1.2$ to 3.2 ; four populations) and $\mathrm{CHC}$ solvents and related compounds $(1.4 ; 95 \%$ CI 1.0 to $1.8 ; 20$ populations). Non-significant excesses over MRR>1.3 were found for PAHs; organochlorine insecticides; silica dust; and chromium and chromium compounds.

Table 3 shows the MRRs after stratification by sex and diagnostic quality. Only seven studies presented results for women. For CHC solvents and related compounds, the MRR for women $(1.8$; $95 \%$ CI 0.7 to 5.8 ; three populations) was higher than for men $(1.3 ; 0.9$ to 1.9 ; 14 populations). The MRR remained essentially unchanged irrespective of whether histological verification of diagnoses of pancreatic cancer was done or not. For chromium and chromium compounds and for PAHs, the excess risks disappeared in studies that had histological diagnoses, whereas for nickel and nickel compounds, the MRR was increased in populations with and without histological verification of the cases. 
Table 3 Populations (n), metarisk estimates (MRRs) (95\% CIs) by occupational agents, sex, and quality of diagnosis: (proportional studies are excluded: simple random effects models with covariates)

\begin{tabular}{|c|c|c|c|c|c|c|c|c|c|c|c|c|c|c|c|}
\hline \multirow[b]{3}{*}{ Agent } & \multicolumn{9}{|c|}{ Sex } & \multicolumn{6}{|c|}{ Histological diagnosis } \\
\hline & \multicolumn{3}{|c|}{ Men } & \multicolumn{3}{|c|}{ Women } & \multicolumn{3}{|c|}{ Unspecified or both } & \multicolumn{3}{|c|}{ Yes } & \multicolumn{3}{|l|}{ No } \\
\hline & $n$ & $M R R$ & $95 \% C I$ & $n$ & $M R R$ & $95 \% C I$ & $n$ & $M R R$ & $95 \% C I$ & $n$ & $M R R$ & $95 \% C I$ & $n$ & $M R R$ & $95 \% C I$ \\
\hline $\begin{array}{l}\text { Aliphatic and alicyclic } \\
\text { hydrocarbon solvents }\end{array}$ & & & & & & & & & & 2 & 1.3 & 0.8 to 2.0 & & & \\
\hline $\begin{array}{l}\text { Aromatic hydrocarbon } \\
\text { solvents }\end{array}$ & 6 & 0.7 & 0.6 to 1.0 & & & & 7 & 1.3 & 0.9 to 1.7 & 4 & 1.0 & 0.6 to 1.8 & 9 & 1.0 & 0.7 to 1.2 \\
\hline Arsenic & 3 & 0.9 & 0.6 to 1.6 & & & & & & & 2 & 1.1 & 0.5 to 2.7 & 2 & 0.9 & 0.5 to 1.6 \\
\hline Asbestos & 18 & 1.3 & 1.0 to 1.5 & 3 & 0.8 & 0.4 to 1.7 & 3 & 0.6 & 0.4 to 0.8 & 3 & 0.7 & 0.4 to 1.2 & 21 & 1.2 & 1.0 to 1.5 \\
\hline $\begin{array}{l}\text { Chlorinated hydrocarbon } \\
\text { solvents and related } \\
\text { compounds }\end{array}$ & 14 & 1.3 & 0.9 to 1.9 & 3 & 1.8 & 0.7 to 4.6 & 3 & 1.6 & 0.8 to 2.9 & 4 & 1.2 & 0.7 to 2.1 & 16 & 1.4 & 1.0 to 2.1 \\
\hline $\begin{array}{l}\text { Chromium and } \\
\text { chromium compounds }\end{array}$ & 7 & 1.8 & 0.9 to 3.6 & & & & 2 & 0.9 & 0.5 to 1.8 & 3 & 1.0 & 0.7 to 1.6 & 6 & 2.3 & 0.9 to 5.8 \\
\hline Diesel engine exhaust & 5 & 1.1 & 0.9 to 1.3 & & & & 2 & 0.9 & 0.6 to 0.9 & 3 & 1.1 & 0.9 to 1.2 & 4 & 1.0 & 0.9 to 1.1 \\
\hline Electromagnetic fields & 6 & 1.1 & 0.9 to 1.3 & & & & & & & & & & 6 & 1.1 & 0.9 to 1.3 \\
\hline Formaldehyde & 3 & 0.8 & 0.5 to 1.3 & & & & 2 & 0.6 & 0.3 to 1.1 & 2 & 0.5 & 0.3 to 0.9 & 3 & 0.9 & 0.7 to 1.3 \\
\hline Gasoline & 2 & 1.0 & 0.8 to 1.3 & & & & & & & 2 & 1.0 & 0.8 to 1.4 & 2 & 0.9 & 0.6 to 1.3 \\
\hline Herbicides & 8 & 1.2 & 0.8 to 2.0 & & & & 2 & 0.9 & 0.7 to 1.2 & & & & 9 & 1.1 & 0.8 to 1.5 \\
\hline Insecticides & 2 & 0.7 & 0.4 to 1.5 & & & & 2 & 3.7 & 0.3 to 43.3 & & & & 3 & 1.2 & 0.3 to 4.3 \\
\hline $\begin{array}{l}\text { Lead and lead } \\
\text { compounds }\end{array}$ & 3 & 1.1 & 0.8 to 1.6 & & & & & & & 2 & 1.1 & 0.8 to 1.6 & 2 & 1.0 & 0.5 to 2.2 \\
\hline Man made vitreous fibres & 2 & 1.8 & 0.8 to 3.8 & & & & 3 & 0.9 & 0.7 to 1.2 & 3 & 0.8 & 0.5 to 1.2 & 2 & 1.2 & 0.8 to 1.6 \\
\hline $\begin{array}{l}\text { Nickel and nickel } \\
\text { compounds }\end{array}$ & 3 & 2.0 & 1.2 to 3.5 & & & & & & & 2 & 2.0 & 1.2 to 3.2 & 2 & 1.6 & 0.4 to 6.9 \\
\hline Oil mist & 4 & 0.9 & 0.8 to 1.0 & & & & 2 & 0.5 & 0.3 to 1.1 & & & & 6 & 0.9 & 0.7 to 1.2 \\
\hline $\begin{array}{l}\text { Polycyclic aromatic } \\
\text { hydrocarbons (PAHs) }\end{array}$ & 3 & 1.8 & 0.8 to 3.4 & & & & & & & 2 & 1.4 & 0.8 to 2.3 & 2 & 3.0 & 0.7 to 13.2 \\
\hline Silica dust & 2 & 1.1 & 0.8 to 1.5 & & & & & & & 2 & 1.5 & 0.8 to 2.6 & & & \\
\hline Wood dust & & & & & & & 3 & 1.1 & 0.7 to 1.7 & 3 & 1.2 & 0.9 to 1.6 & & & \\
\hline
\end{tabular}

Table 4 presents results by study type. For $\mathrm{CHC}$ solvents and related compounds, cohort studies with internal reference and case-control studies yielded an MRR of 1.4 (95\% CI 0.8 to 2.4; four populations). In studies that used general populations as the reference (SMR/SIR studies), MRR was 1.3 (0.9 to $2.0 ; 16$ populations). For the lower quality proportional studies, it was 1.1 (0.9 to 1.3; four populations).

For nickel and nickel compounds the MRR was highest for case-control studies $(2.0 ; 95 \%$ CI 1.2 to 3.2 ; two populations). For chromium and chromium compounds it was highest in SMR/SIR studies $(2.3 ; 0.9$ to 5.8 ; six populations), as for PAHs it was (3.0; 0.7 to 13.2 ; two populations).
For asbestos, the $20 \mathrm{SMR} / \mathrm{SIR}$ populations yielded a significant MRR of 1.2 (95\% CI 1.0 to 1.5$)$, whereas the four case-control populations resulted in an MRR of 0.7 (0.5 to 1.0$)$.

Two cohort studies with an internal reference yielded a significant MRR of $1.4(95 \% \mathrm{CI}$ 1.3 to 1.9) for diesel engine exhaust, which was, however, not confirmed in case-control and SMR/SIR studies, the overall MRR remaining at 1.0 (95\% CI 0.9 to 1.2$)$.

For insecticides, the overall MRR was 1.5 (95\% CI 0.6 to 3.7 ). For the two case-control studies, both based on cytological diagnoses, it was 3.7 (95\% CI 0.3 to 43.3 ), which was not confirmed in the one occupational cohort mortality study. All insecticide results

Table 4 Populations (n), metarisk ratios (MRRs) (95\% CIs), by study type (proportional studies excluded: simple random effects models with no covariates)

\begin{tabular}{|c|c|c|c|c|c|c|}
\hline \multirow[b]{2}{*}{ Agent } & \multicolumn{3}{|c|}{$\begin{array}{l}\text { Case-control studies and cohort } \\
\text { studies with internal reference }\end{array}$} & \multicolumn{3}{|c|}{ SMR/SIR studies } \\
\hline & $n$ & $M R R$ & $95 \% C I$ & $n$ & $M R R$ & $95 \% C I$ \\
\hline Aliphatic and alicyclic hydrocarbon solvents & 2 & 1.3 & 0.8 to 2.0 & & & \\
\hline Aromatic hydrocarbon solvents & 4 & 0.9 & 0.5 to 1.6 & 9 & 1.0 & 0.8 to 1.3 \\
\hline Arsenic & 3 & 1.2 & 0.5 to 2.6 & 1 & 0.9 & 0.4 to 1.5 \\
\hline Asbestos & 4 & 0.7 & 0.5 to 1.0 & 20 & 1.2 & 1.0 to 1.5 \\
\hline Cadmium and cadmium compounds & 1 & 0.8 & 0.2 to 2.9 & 1 & 0.7 & 0.3 to 1.4 \\
\hline Chlorinated hydrocarbon solvents and related compounds & 4 & 1.4 & 0.8 to 2.4 & 16 & 1.3 & 0.9 to 2.0 \\
\hline Chromium and chromium compounds & 3 & 1.0 & 0.7 to 1.6 & 6 & 2.3 & 0.9 to 5.8 \\
\hline Diesel engine exhaust & 5 & 1.1 & 0.9 to 1.4 & 2 & 0.9 & 0.8 to 1.1 \\
\hline Electromagnetic fields & & & & 5 & 1.1 & 0.8 to 1.4 \\
\hline Flour dust & 1 & 1.1 & 0.3 to 3.2 & & & \\
\hline Formaldehyde & 2 & 0.5 & 0.3 to 1.6 & 3 & 0.9 & 0.7 to 1.3 \\
\hline Fungicides & 2 & 1.3 & 0.3 to 3.8 & & & \\
\hline Gasoline & 2 & 1.0 & 0.8 to 1.4 & 2 & 0.9 & 0.6 to 1.3 \\
\hline Herbicides & 1 & 0.9 & 0.7 to 1.8 & 9 & 1.0 & 0.8 to 1.3 \\
\hline Insecticides & 2 & 3.7 & 0.3 to 43.3 & 1 & 0.8 & 0.3 to 1.7 \\
\hline Iron and iron compounds & 1 & 1.3 & 0.7 to 2.5 & & & \\
\hline Lead and lead compounds & 3 & 1.1 & 0.8 to 1.6 & 1 & 1.0 & 0.4 to 2.1 \\
\hline Man made vitreous fibres & 4 & 0.9 & 0.4 to 2.2 & 1 & 1.1 & 0.8 to 1.5 \\
\hline Nickel and nickel compounds & 2 & 2.0 & 1.2 to 3.2 & 2 & 1.6 & 0.4 to 6.9 \\
\hline Oil mist & 3 & 0.8 & 0.6 to 1.3 & 3 & 0.9 & 0.7 to 1.0 \\
\hline Polycyclic aromatic hydrocarbons (PAHs) & 2 & 1.4 & 0.8 to 2.3 & 2 & 3.0 & 0.7 to 13.2 \\
\hline Silica dust & 2 & 1.5 & 0.8 to 2.7 & 1 & 1.2 & 0.6 to 2.1 \\
\hline Wood dust & 4 & 1.2 & 0.9 to 1.6 & & & \\
\hline
\end{tabular}


Table 5 Populations (n), population aetiological fractions (PEFs), aetiological fractions among exposed (EEFs), (95\%CIs)

\begin{tabular}{|c|c|c|c|c|c|c|c|c|c|c|c|}
\hline \multirow[b]{2}{*}{ Agent } & \multicolumn{6}{|c|}{ Population aetiological fraction (PEF) } & \multicolumn{5}{|c|}{ Aetiological fraction among exposed (EEF) } \\
\hline & $n$ & $\begin{array}{l}\text { Proportion } \\
\text { exposed }\end{array}$ & $M R R$ & $95 \% C I$ & $P E F$ & $95 \% C I$ & $n$ & $M R R$ & $95 \% C I$ & $E E F$ & $95 \% C I$ \\
\hline Aliphatic and alicyclic hydrocarbon solvents & 2 & 0.094 & 1.3 & 0.8 to 2.0 & 0.022 & 0.00 to 0.047 & 2 & 1.3 & 0.8 to 2.0 & 0.23 & 0.00 to 0.50 \\
\hline Chlorinated hydrocarbon solvents and & & & & & & & & & & & $0 \Omega 0$ to 0 - \\
\hline Chromium and chromium compounds & 3 & $\begin{array}{l}0.061 \\
0.034\end{array}$ & $\begin{array}{l}1.2 \\
1.1\end{array}$ & $\begin{array}{l}0.7 \text { to } 1.9 \\
0.7 \text { to } 1.6\end{array}$ & 0.003 & 0.00 to 0.013 & $\begin{array}{r}20 \\
9\end{array}$ & $\begin{array}{l}1.4 \\
1.4\end{array}$ & $\begin{array}{l}1.0 \text { to } 1.8 \\
0.9 \text { to } 2.3\end{array}$ & $\begin{array}{l}0.29 \\
0.29\end{array}$ & $\begin{array}{l}0.00 \text { to } 0.44 \\
0.00 \text { to } 0.57\end{array}$ \\
\hline Fungicides & 1 & 0.0034 & 1.4 & 0.3 to 7.2 & 0.001 & 0.00 to 0.0029 & 2 & 1.3 & 0.4 to 3.8 & 0.23 & 0.00 to 0.74 \\
\hline Insecticides & & & & & & & 3 & 1.5 & 0.6 to 3.7 & 0.33 & 0.00 to 0.73 \\
\hline Iron and iron compounds & 1 & 0.067 & 1.3 & 0.7 to 2.5 & 0.016 & 0.00 to 0.040 & 1 & 1.3 & 0.7 to 2.5 & 0.23 & 0.00 to 0.60 \\
\hline Lead and lead compounds & 2 & 0.11 & 1.1 & 0.8 to 1.6 & 0.010 & 0.00 to 0.041 & 4 & 1.1 & 0.8 to 1.5 & 0.09 & 0.00 to 0.33 \\
\hline Nickel and nickel compounds & 2 & 0.063 & 2.0 & 1.2 to 3.2 & 0.032 & 0.011 to 0.043 & 4 & 1.9 & 1.2 to 3.2 & 0.47 & 0.17 to 0.69 \\
\hline Polycyclic aromatic hydrocarbons (PAHs) & 2 & 0.029 & 1.4 & 0.8 to 2.3 & 0.008 & 0.00 to 0.016 & 4 & 1.5 & 0.9 to 2.4 & 0.33 & 0.00 to 0.58 \\
\hline Silica dust & 2 & 0.063 & 1.5 & 0.8 to 2.7 & 0.021 & 0.00 to 0.040 & 3 & 1.4 & 0.9 to 2.0 & 0.29 & 0.00 to 0.50 \\
\hline Wood dust & 4 & 0.062 & 1.2 & 0.9 to 1.6 & 0.01 & 0.00 to 0.023 & 5 & 1.2 & 0.9 to 1.6 & 0.17 & 0.00 to 0.38 \\
\hline
\end{tabular}

Only agents with both MRRs $>1.0$ considered. Negative lower confidence bounds of PEFs and EEFs forced to zero.

$M R R=$ meta risk ratio, as estimated from population based and hospital based case-control studies for PFF, and all but proportional studies for EEF.

concerned organochlorine compounds. There were 12 further studies that considered unspecified pesticides. This group of agents was considered to be too heterogeneous in exposures and was dropped from the analysis.

Given the low proportions of the populations that were exposed, the PEFs remained low, from $0.1 \%-3 \%$ (table 5). Assuming independence between exposures, summing up of the PEFs resulted in an overall aetiological fraction of $12 \%$ for workplace exposures. The agent specific EEFs ranged from $9 \%$ to $47 \%$, with wide $95 \%$ CIs. In a subpopulation exposed to nickel and nickel compounds, the EEF was $47 \%$ (95\% CI 17 to $69 \%$ ); to PAHs, $33 \%$ (0 to $58 \%$ ); to insecticides, $33 \%$ (0 to $73 \%$ ); to $\mathrm{CHC}$ solvents and related compounds, $29 \%$ (0 to $44 \%)$; to chromium and chromium compounds, $29 \%$ (0 to $57 \%$ ); and to aliphatic and alicyclic solvents, $23 \%$ (0 to $50 \%$ ).

\section{Discussion}

EVIDENCE

The excess risk found for $\mathrm{CHC}$ solvents and related compounds was based on 20 populations. Heterogeneity of RRs was nearly significant and may be explained by differences in the quality and exposure level of the agents. Various compounds with variable carcinogenic potential were mentioned as worker exposures: trichloroethylene, tetrachloroethylene, 1,1,1trichloroethane, methylene chloride, vinyl chloride, ethylene chlorohydrine, ethylene dichloride, bis(chloromethyl)ether, and polychlorinated biphenyls. Intensities and long term doses were characterised in most of the studies either poorly or not at all.

The risk for nickel and nickel compounds was most evident in population based casecontrol studies. For chromium and chromium compounds, the MRR was non-significantly increased in all studies, but was not in excess in population based case-control studies. For PAHs, a non-significant increase was present in all studies, in population-based case-control studies, and in the two SMR/SIR studies. These findings could have occurred by chance.

The excess of silica dust reached significance in one $^{52}$ of three studies. This same Finnish population-based case-control study found a significant excess for aliphatic and alicyclic hydrocarbon solvents. This finding was aggre- gated with the finding of no excess for alkanes $\left(\mathrm{C}_{5}-\mathrm{C}_{17}\right)$ in another population based study from Montreal, ${ }^{79}$ the result being an MRR of 1.3 (95\% CI 0.8 to 2.0 ).

Two case-control studies, ${ }^{41}{ }^{42}$ both based on cytological diagnoses, one SMR study, ${ }^{24}$ and one PMR study ${ }^{31}$ considered exposure to organochlorine insecticides. The insecticidal agents listed as exposures were 1,1-bis(4chlorophenyl)-2,2,2-trichloroethane (DDT), chlordane, heptachlor, endrin, aldrin, dieldrin, bulan, chlorfenethol, chloropropylate, dicofol, ethylan, methoxychlor, and tetrachlorodiphenylethane (TDE). Excluding the PMR study, the aggregated MRR was 1.5 (95\% CI 0.6 to 3.7). In case-control studies it was 3.7 (0.3 to 43) based on the random effects model, and 1.7 (0.9 to 3.2) based on the fixed effects model (heterogeneity $p=0.09$ ). The highest RR was obtained for exposure to the DDT family (DDT, ethylan, DDD; OR 21.0; 95\% CI 2.6 to 966; five exposed cases) in a case-control study nested in a chemical manufacturing cohort. ${ }^{42}$ Potential confounders included nitrophenol derivatives, clays, $N, N$-dimethylformamide, dispersing agents, octane, and carbon tetrachloride. The other case-control study ${ }^{41}$ was population based (Michigan, US), with self reported exposures. Based on 21 exposed cases, it yielded an OR of 1.5 (95\% CI 0.8 to 2.9) for organochlorine insecticides. Assuming an effect, the difference between the two point estimates might be due to qualitative and quantitative differences in exposures between manufacturing and agricultural application.

There is a possibility of effect modification of environmental or occupational determinants by lifestyles (tobacco, alcohol, coffee) or dietary factors. These interactions were not considered in the studies. Also, genetic factors may interact with environmental or occupational exposures.

\section{COMBINABILITY AND HETEROGENEITY}

Epidemiological meta-analyses have imperfect combinability of results associated with different study types, methods, populations, exposure circumstances, and diagnostic specificities. We calculated MRRs including and excluding the poorest quality studies (proportional studies). We also calculated separate MRRs for cohort studies with internal controls, 
case-control studies, SMR/SIR studies, and the few proportional studies. Differences in results from different study types were not consistent.

Several populations were poorly characterised. There were even studies that did not specify whether the cohort consisted of men, women, or both. We analysed the data for known male and female populations separately, and found data for women to be associated with a slightly higher MRR than data for men for CHC solvents and related compounds.

There was in all likelihood substantial heterogeneity across populations in the quality and intensity of exposure categories, in the intake route (respiratory, dermal, or other) of exposure, time aspects of exposure (period, latency, duration, quality, and intensity), and applied scales of exposure, as well as in the quality of diagnosis of pancreatic cancer. Qualitative and quantitative differences in exposures have already been exemplified in connection with $\mathrm{CHC}$ solvents and related compounds and organochlorine insecticides. Based on a rough statistical test, significant heterogeneity of risk was found for asbestos, electromagnetic fields, $\mathrm{CHC}$ solvents and related compounds, and man made vitreous fibres. Some studies did not document the exposure aspects at all, and no study provided a full documentation. Expert assessments, which represent an imperfect yet acceptable method of exposure assessment, were used in 25 populations. Industrial hygiene measurements that represent a certain degree of objectivity were used as the prime source of exposure data in only four populations. Exposure assessment based on job titles (57 populations) are of lower quality, unless the exposures are highly homogeneous within job titles. However, some of the populations represented rather homogeneous single title cohorts. Job exposure matrices assess exposures better if the matrix is specific for branch and job title, even for company and period. The JEMs of variable degree of specificity were applied in 15 populations. Most were relatively unspecific and thereby induced exposure misclassification. Misclassification, however, was likely to be non-differential, resulting in underestimation of the MRR. Multiple sources of exposure data were applied in 37 populations. Exposure data were longitudinal in 127 populations and lifelong in 47 populations. The longitudinality of exposures was thus well covered.

Misclassification rates for pancreatic cancer are marked, particularly when the diagnosis is based on death certificate only. This adds to the bias in the meta estimates towards the null value. Garabrandt et $a l^{42}$ showed what the magnitude of the impact may be in a single study. They compared, in a case-control study of pancreatic cancer, ORs for the DDT family between cases representing death certificates and cases representing cytological verification. For death certificate cases the ORs ranged from 0.8 to 2.6 ; for cytologically verified cases, from 15.4 to infinity. In our meta-analysis, agent specific MRRs were higher for nine agents but lower for 10 agents in populations in

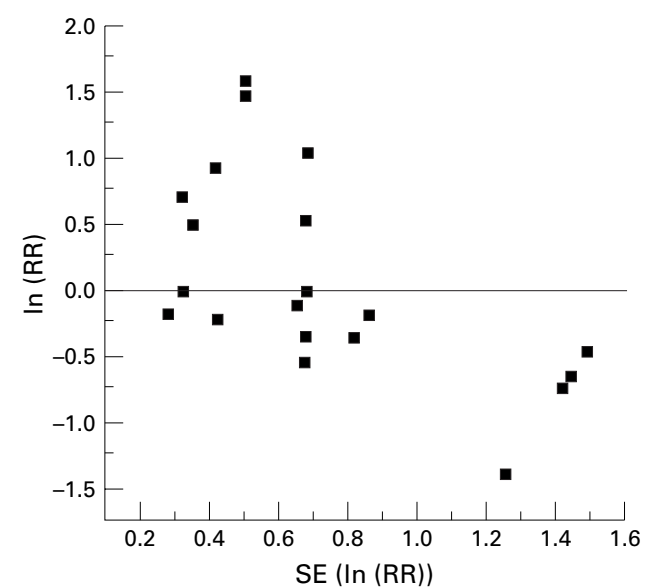

Funnel plot for chlorinated hydrocarbon solvents. Natural log of risk ratio (n (RR)) plotted against imprecision (SE of $\ln (R R))$. The unit of the plot is study population.

which histological verification was applied, compared with no histological verification. For CHC solvents and related compounds, the two MRRs were practically identical. For PAHs and chromium, the MRRs were higher in populations with histological diagnoses.

\section{PUBLICATION BIAS}

Publication bias is not likely in this study, as very few small studies expressly considered the occupational determinants of pancreatic cancer. Non-positive occupational findings from small studies therefore were not likely to remain unpublished. Also, a funnel plot for $\mathrm{CHC}$ solvents and related compounds, for which an excess risk was found (figure), did not identify a concentration of small studies (high $\mathrm{SE}$ of $\ln (\mathrm{RR})$ ) at high RRs. Publication bias therefore may be claimed to be minimal or non-existent. Negative results based on reasonably large numbers are unlikely to remain unpublished.

A counterargument may be raised about cohort studies with multiple end points. Some of these studies deleted results based on small numbers, occasionally for pancreatic cancer. This omission may have minor influence on the metaresults. Some case-control studies may have omitted results for rare exposures, with similar minor effect on the metaresults.

\section{SELECTION OF STUDIES}

We used major databases and lists of references of the studies for the identification of studies. Studies not found in major databases are probably of lower quality. For the same reason and because of the cost we did not try to identify unpublished studies.

\section{EXTRACTION}

Extractor bias was minimised by the formal extraction procedure between the extractors, and the central checking of the extraction. The procedure was also intended to guarantee the extraction of the relevant risk estimates in studies that offered several alternative risk estimates. 
REFERENCE POPULATIONS

Not all populations in the data were strictly independent because in some studies an internal unexposed industrial population was used as the common reference for more than one exposed population. This was rare, however, and we consider the ensuing bias in the precision of MRR to be minimal. Reference populations are a problem in proportional studies, where the population basis is unknown. For most analyses, we excluded proportional studies for this reason. Comparability of populations may be a problem in SMR and SIR studies because of the healthy worker effect. It is unknown to what extent the healthy worker effect and its components might have biased our metaresults.

CONFOUNDING

Control of confounding is a problem in studies of pancreatic cancer, as tobacco smoking and diabetes are the only known common causes of this malignancy. Even a rough measurement of confounding bias is difficult. Case-control studies are in principle best equipped for adjustment for confounders. Several of them did adjust for various factors. In other study types, adjustment was rare. Attempts to aggregate results over studies that adjusted for smoking failed because of small numbers of such studies. The number of available populations for which adjustment was done ranged from zero to two across the occupational agents.

\section{AETIOLOGICAL FRACTIONS}

Aetiological fractions were unstable both statistically and substantially. The PEFs were highly dependent of the variable occupational exposure patterns across populations and periods. The variability concerns the proportions of exposed subjects, and intensities and time patterns of exposures. Also, the technical definitions of exposed varied between studies. The same holds for EEFs, with the exception that the proportion of exposed subjects is not a concern.

\section{Conclusions}

The aetiological fraction of pancreatic cancer due to occupational exposures within a population was estimated at $12 \%$. This may be an underestimate because of misclassification of exposures and end points in the studies. The aetiological fractions among exposed subjects was highest at $47 \%$ in people occupationally exposed to nickel and nickel compounds. The implication is that if smoking explains $20 \%$ $25 \%$ of pancreatic cancers and occupational and general environmental factors $15 \%-20 \%$ at maximum in a typical "western" adult population, the bulk of the risk remains unexplained. Further risk factors are likely to be found in inherited susceptibility, dietary habits, interactions between lifestyles, environmental, occupational, and genetic factors, or other yet unrecognised factors.

Results of this metaanalysis suggest that occupational exposure to some CHC solvents and related compounds may increase the risk of pancreatic cancer. The excess may be pronounced in women. Excesses associated with occupational exposure to chromium and chromium compounds and nickel and nickel compounds were suggested. More limited evidence was found for organochlorine insecticides, silica dust, and aliphatic and alicyclic hydrocarbon solvents.

Future research into the aetiology of pancreatic cancer should concentrate on more refined assessment of exposure and end points, assessment of interactions between occupational and environmental factors, lifestyle (tobacco, alcohol, coffee, diet), and interactions between genes and the environment. Future research therefore calls for large studies, complex measures, and refined statistical methods.

The Finnish Work Environment Fund has supported this study. Ms Ritva Järnström and Mr Tuomas Hanhinen created the refMs Ritva Järnstrom
erence database.

1 Finnish Cancer Registry. Cancer incidence in Finland 1995. Helsinki: Cancer Statistics of the National Research and Development Centre for Welfare and Health, 1997.

2 Faggiano F, Partanen T. Socioeconomic differences in cancer incidence and mortality. In: Kogevinas M, Pearce N, Susser $\mathrm{M}$, et al, eds. Social inequalities and cancer. Lyon: International Agency for Research on Cancer: 1997. (IARC Sci Publ No 138.)

3 Weiderpass E, Partanen T, Kaaks R, et al. Occurrence, trends and environment etiology of pancreatic cancer. Scand 7 Work Environ Health 1998;24:165-74.

4 Fernandez E, La Vecchia C, Porta $M$, et al. Trends in pancreatic cancer mortality in Europe, 1955-89. Int f Cancer 1994;57:786-92.

5 Porta M, Malats N, Piñol JL, et al. Response. I Clin Epidemiol 1996;49:602-3.

6 Malats N, Real FX, Porta M. DDT and pancreatic cancer. 7 Natl Cancer Inst 1993;85:328.

7 Kauppinen T, Toikkanen J, Pukkala E. From crosstabulations to multipurpose information systems: a new job-exposure matrix. Am f Ind Med 1998;33:409-17.

8 Acheson ED, Gardner MJ, Winter PD, et al. Cancer in a factory using amosite asbestos. Int $\mathcal{F}$ Epidemiol 1984;13:310.

9 Acquavella J, Leet T, Johnson G. Occupational experience and mortality among a cohort of metal components manufacturing workers. Epidemiology 1993;4:428-34.

10 Andersson K, Elinder CG, Hogstedt C, et al. Mortality among cadmium and nickel-exposed workers in a Swedish battery factory. Current Topics in Environmental and Toxicological Chemistry 1985;8:399-408.

11 Anttila A, Pukkala E, Sallmén M, et al. Cancer incidence among Finnish workers exposed to halogenated hydrocarbons. F Occup Environ Med 1995;37:797-806.

12 Anttila A, Pukkala E, Riala R, et al. Cancer incidence among Finnish workers exposed to aromatic hydrocarbons. Int Arch Occup Environ Health 1998;71:187-93.

13 Armstrong BK, McNulty JC, Levitt LJ, et al. Mortality in gold and coal miners in Western Australia with special reference to lung cancer. Br F Ind Med 1979;36:199-205.

14 Asp S, Riihimäki V, Hernberg S, et al. Mortality and cancer morbidity of Finnish chlorophenoxy herbicide applicators: an 18-year prospective follow-up. Am $\mathcal{F}$ Ind Med 1994;26: $243-53$

15 Axelson O, Selden A, Andersson K, et al. Updated and expanded Swedish cohort study on trichloroethylene and cancer risk. F Occup Med 1994;36:556-62.

16 Axelsson G, Rylander R, Schmidt A. Mortality and incidence of tumours among ferrochromium workers. $\mathrm{Br} \mathcal{F}$ Ind Med 1980;37:121-7.

17 Bardin J, Eisen PE, Hallock MF, et al. Mortality studies of machining fluid exposure in the automobile industry. V: a machining fluid exposure in the automobile industry. V: a
case control study of pancreatic cancer. Am $\mathcal{F}$ Ind Med 1997;32:240-7.

18 Baris D, Armstrong BG, Deadman J, et al. A mortality study of electrical utility workers in Quebec. Occup Environ Med 1996;53:25-31

19 Benson LO, Teta MJ. Mortality due to pancreatic and lymphopoietic cancers in chlorohydrin production workers. $\mathrm{Br}$ f Ind Med 1993;50:710-16.

20 Boffetta P, Stellman SD, Garfinkel L. Diesel exhaust exposure and mortality among males in the American Cancer Society prospective study. Am f Ind Med 1988;14:403-15.

21 Boffetta P, Saracci R, Andersen A, et al. Cancer mortality among man-made vitreous fiber production workers. Epidemiology 1997;8:259-68.

22 Bond GG, Bodner KM, Olsen GW, et al. Mortality among workers engaged in the development or manufacture of workers engaged in the development or manufacture of Health 1992;18:145-54.

23 Brown DP. Mortality of workers exposed to polychlorinated biphenyls: an update. Arch Environ Health 1987;42:333-9. 
24 Brown DP. Mortality of workers employed at organochlorine pesticide manufacturing plants: an update. Scand $\mathscr{f}$

25 Brown DP, Dement JM, Okun A. Mortality patterns among female and male chrysotile asbestos textile workers. $\mathscr{J}$ Occup Med 1994;36:882-8.

26 Cammarano G, Crosignani P, Berrino H, et al. Additional follow up of cancer mortality among workers in a thermoelectric power plant. Scand $\mathcal{F}$ Work Environ Health 1986;12: 631-2.

27 Checkoway H, Heyer NJ, Seixas NS, et al. Dose-response associations of silica with non-malignant respiratory disease and lung cancer mortality in the diatomaceous earth industry. Am F Epidemiol 1997;145:680-8.

28 Chiazze LJ, Ference LD. Mortality among PVC-fabricating employees. Environ Health Perspect 1981;41:137-43.

29 Claude J, Frentzel-Beyme R. Mortality of workers in a German rock-wool factory: a second look with extended follow up. Scand f Work Environ Health 1986;12:53-60.

30 Cocco P, Hua F, Boffetta P, et al. Mortality of Italian lead smelter workers. Scand $\mathcal{f}$ Work Environ Health 1997;23:1523.

31 Cocco P, Blair A, Congia P, et al. Long term health effects of the occupational exposure to DDT. A preliminary report. Ann N Y Acad Sci 1997;837:246-56.

32 Coggon D, Pannett B, Winter PD, et al. Mortality of workers exposed to 2 methyl-4 chlorophenoxyacetic acid. Scand f Work Environ Health 1986;12:448-54.

33 Decoufle P. Further analysis of cancer mortality patterns among workers exposed to cutting oil mists. 7 Natl Cancer Inst 1978;61:1025-30.

34 Decouflé P, Blattner WA, Blair A. Mortality among chemical workers exposed to benzene and other agents. Environ Res 1983;30:16-25.

35 Dement JM, Brown DP, Okun A. Follow up study of chrysotile asbestos textile workers: cohort mortality and
case-control analyses. Am f Ind Med 1994;26:431-47.

36 Elinder CG, Kjellström T, Hogstedt C, et al. Cancer mortality of cadmium workers. Br f Ind Med 1985;42:6515 .

37 Enterline PE, Hartley J, Henderson V. Asbestos and cancer: a cohort followed up to death. Br F Ind Med 1987;44:396401

38 Enterline PE, Day R, Marsh GM. Cancers related to exposure to arsenic at a copper smelter. Occup Environ Med 1995;52:28-32.

39 Franchini I, Magnani F, Mutti A. Mortality experience among chromeplating workers. Initial findings. Scand $\mathscr{f}$ Work Environ Health 1983;9:247-52.

40 Frentzel-Beyme R, Thiess AM, Wieland R. Survey of mortality among employees engaged in the manufacture of styrene and polystyrene at the BASF Ludwigshafen works. rene and polystyrene at the BASF Ludwigsh
Scand 7 Work Environ Health 1978;4:231-9.

41 Fryzek JP, Garabrant DH, Harlow SD, et al. A case-control study of self reported exposures to pesticides and pancreas cancer in southeastern Michigan. Int 7 Cancer 1997;72:627.

42 Garabrant DH, Held J, Homa D. Response (DDT and pancreatic cancer). F Natl Cancer Inst 1993;85:328-9.

43 Gardner MJ, Pannett B, Winter PD, et al. A cohort study of workers exposed to formaldehyde in the British chemical industry: an update. Br F Ind Med 1993;50:827-34.

44 Gibbs GW, Amsel J, Soden K. A cohort mortality study of cellulose triacetate-fibre workers exposed to methylene chloride. F Occup Environ Med 1996;38:693-7.

45 Greenland S, Salvan A, Wegman DH, et al. A case-control study of cancer mortality at a transformer-assembly facility. Int Arch Occup Environ Health 1994;66:49-54.

46 Gustavsson P, Reuterwall C. Mortality and incidence of cancer among Swedish gas workers. Br F Ind Med 1990;47: $169-74$

47 Hansen J, Olsen JH. Formaldehyde and cancer morbidity among male employees in Denmark. Cancer Causes Contro 1995;6:354-60

48 Hearne FT, Pifer JW, Grose F. Absence of adverse mortality effects in workers exposed to methylene chloride: an update. $\mathcal{F}$ Occup Med 1990;32:234-40.

49 Hooiveld M, Heederik DJJ, Kogevinas M, et al. Second follow-up of a Dutch cohort occupationally exposed to phenoxy herbicides, chlorophenols, and contaminants. $A m$ $\mathcal{F}$ Epidemiol 1998;147:891-901.

50 Howe GR, Fraser D, Lindsay J, et al. Cancer mortality $(1965-77)$ in relation to diesel fume and coal exposure in a cohort of retired railway workers. I Natl Cancer Inst 1983;70:1015-9.

51 Kano K, Horikawa M, Utsunomiya T, et al. Lung cancer mortality among a cohort of male chromate pigment workmortality among a cohort of male chromate

52 Kauppinen T, Partanen T, Degerth R, et al. Pancreatic cancer and occupational exposures. Epidemiol 1995;6:498502 .

53 Kogevinas M, Ferro G, Andersen A, et al. Cancer mortality in a historical cohort study of workers exposed to styrene. Scand $\mathcal{F}$ Work Environ Health 1994;20:251-61.

54 Kogevinas M, Becher H, Benn T, et al. Cancer mortality in workers exposed to phenoxy herbicides, chlorophenols, and dioxins. An expanded and updated internationa cohort study. Am f Epidemiol 1997;145:1061-75.

55 Lanes SF, Rothman KJ, Dreyer NA, et al. Mortality update of cellulose fiber production workers. Scand 7 Work Environ Health 1993;19:426-8.

56 Langård S, Andersen A, Ravnestad J. Incidence of cancer among ferrochromium and ferrosilicon workers: an extended observation period. Br f Ind Med 1990;47:14-9.
57 Leet T, Acquavella J, Lynch C, et al. Cancer incidence among alachlor manufacturing workers. Am 7 Ind Med 1996;30:300-6

58 Levine RJ, Andjelkovich DA, Shaw LK. The mortality of Ontario undertakers and a review of formaldehyde- related mortality studies. F Occup Med 1984;26:740-6.

59 Lynge E. A follow-up study of cancer incidence among mark. Br F Cancer 1985;52:259-70.

60 Lynge E, Andersen A, Nilsson R, et al. Risk of cancer and exposure to gasoline vapors. Am F Epidemiol 1997;145:44958.

61 Mack TM, Peters JM, Yu MC, et al. Pancreas cancer is unrelated to the workplace in Los Angeles. Am 7 Ind Med 1985;7:253-66.

62 Magnani C, Coggon D, Osmond C, et al. Occupation and five cancers: a case-control study using death certificates. Br F Ind Med 1987;44:769-76.

63 Magnani C, Terracini B, Ivaldi C, et al. Tumor mortality and death from other causes in asbestos cement workers at the Casale Montferrato plant. Med Lav 1996;87:133-46.

64 McDonald JC, Liddell FD, Dufresne A, et al. The 1891-1920 birth cohort of Quebec chrysotile miners and millers: mortality 1976-88. Br f Ind Med 1993;50:107381 .

65 Mikoczy Z, Schütz A, Strömberg U, et al. Cancer incidence and specific occupational exposures in the Swedish leather tanning industry: a cohort based case-control study. Occup Environ Med 1996;53:463-7.

66 Milham SJ. Mortality in workers exposed to electromagnetic fields. Environ Health Perspect 1985;62:297-300.

67 Milham SJ. Increased mortality in amateur radio operators due to lymphatic and hematopoietic malignancies. Am f Epidemiol 1988;127:50-4

68 Moulin JJ, Wild P, Mur JM, et al. Risk of lung, larynx, pharynx, and buccal cavity cancers among carbon electrode 15:30-7.

69 Nakamura K. A mortality study of vinyl chloride workers in Japan. Sangyo Ika Daigaku Zasshi 1983;20:49-57.

70 Ohlson CG, Klaesson B, Hogstedt C. Mortality among asbestos-exposed workers in a railroad workshop. Scand $\mathcal{F}$ Work Environ Health 1984;10:283-91.

71 Ott MG, Olson RA, Cook RR, et al. Cohort mortality study of chemical workers with potential exposure to the higher chlorinated dioxins. F Occup Med 1987;29:422-9.

72 Park RM, Mirer FE. A survey of mortality at two automotive engine manufacturing plants. $A m$ f Ind Med 1996;30:664-73.

73 Ramlow JM, Spadacene NW, Hoag SR, et al. Mortality in a cohort of pentachlorophenol manufacturing workers, 1940-89. Am f Ind Med 1996;30:180-94.

74 Sathiakumar N, Delzell E, Cole P. Mortality among workers at two triazine herbicide manufacturing plants. Am $\mathcal{F}$ Ind Med 1996;29:143-51.

75 Sathiakumar N, Delzell E, Hovinga M, et al. Mortality from cancer and other causes of death in synthetic rubber workers. Occup Environ Med 1998;55:230-5.

76 Seidman H, Selikoff IJ, Gelb SK. Mortality experience of amosite asbestos factory workers: dose-response relationships 5-40 years after onset of short-term work exposure. Am f Ind Med 1986;10:479-514.

77 Selikoff IJ, Seidman H. Cancer of the pancreas among asbestos insulation workers. Cancer 1981;47:1469-73.

78 Sheffet A, Thind I, Miller AM, et al. Cancer mortality in a pigment plant utilizing lead and zinc chromates. Arch Environ Health 1982;37:44-52.

79 Siemiatycki J. Risk factors for cancer in the workplace. Boca Raton, FL: CRC, 1991.

80 Simonato L, L'Abbe KA, Andersen A, et al. A collaborative study of cancer incidence and mortality among vinyl chloride workers. Scand f Work Environ Health 1991;17:15969

81 Sinks T, Steele G, Smith AB, et al. Mortality among workers exposed to polychlorinated biphenyls. Am $\mathcal{F}$ Epidemiol 1992;136:389-98.

82 Smulevich VB, Fedotova IV, Filatova VS. Increasing evidence of the rise of cancer in workers exposed to vinyl chloride. Br F Ind Med 1988;45:93-7.

83 Spirtas R, Stewart PA, Lee JS, et al. Retrospective cohort mortality study of workers at an aircraft maintenance facility. I. Epidemiological results. Br F Ind Med 1991;48:51530 .

84 Stayner LT, Elliott L, Blade L, et al. A retrospective cohort mortality study of workers exposed to formaldehyde in the garment industry. Am f Ind Med 1988;13:667-81.

85 Sun J, Shabata E, Nisanaga N, et al. A cohort mortality study of construction workers. Am F Ind Med 1997;32:35-

86 Swaen GM, van Vliet C, Slangen JJ, et al. Cancer mortality among licensed herbicide applicators. Scand $\mathcal{F}$ Work Environ Health 1992;18:201-4.

87 Tolbert PE, Eisen EA, Pothier LJ, et al. Mortality studies of machining-fluid exposure in the automobile industry. II. Risks associated with specific fluid types. Scand 7 Work Environ Health 1992;18:351-60.

88 Tollestrup K, Daling JR, Allard J. Mortality in a cohort of orchard workers exposed to lead arsenate pesticide spray. Arch Environ Health 1995;50:221-9.

89 Tomenson JA, Bonner SM, Heijne CG, et al. Mortality of workers exposed methylene chloride employed at a plant producing cellulose triacetate film base. Occup Environ Med 1997;54:470-6. 
90 Tsai SP, Waddell LC, Gilstrap EL, et al. Mortality among maintenance employees potentially exposed to asbestos in a refinery and petrochemical plant. Am f Ind Med 1996;29:

91 Tynes T, Andersen A, Langmark F. Incidence of cancer in Norwegian workers potentially exposed to electromagnetic fields. Am F Epidemiol 1992;136:81-8.

92 Tynes T, Reitan JB, Andersen A. Incidence of cancer among workers in Norwegian hydroelectric power companies. Scand 7 Work Environ Health 1994;20:339-44.

93 Van Den Eeden SK, Friedman GD. Exposure to engine exhaust and risk of subsequent cancer. F Occup Med 1993; 35:307-11.

94 Wilczynska U, Szeszenia Dabrowska N, Szymczak W. Mortality from malignant neoplasms in men occupationally exposed to asbestos dust. $M e d \operatorname{Pr} 1996 ; 47: 437-43$.

95 Woitowitz HJ, Lange HJ, Beierl L, et al. Mortality rates in the Federal Republic of Germany following previous occupational exposure to asbestos dust. Int Arch Occup Environ pational exposure to asb $1986 ; 57: 161-71$.
96 Wong O. An industry wide mortality study of chemical workers occupationally exposed to benzene. I. General workers occupationally exposed to ben
results. Br f Ind Med 1987;44:365-81.

97 Wong O, Whorton MD, Foliart DE, et al. An industry-wide epidemiologic study of vinyl chloride workers, 1942-82. epidemiologic study of vinyl ch.

98 Wong O, Trent LS, Whorton MD. An updated cohort mortality study of workers exposed to styrene in the reinforced plastics and composites industry. Occup Environ Med 1994; 51:386-96.

99 Yassi A, Tate R, Fish D. Cancer mortality in workers employed at a transformer manufacturing plant. Am f Ind Med 1994;25:425-37.

100 Breslow NE, Day NE. Statistical methods in cancer research. Vol II. The design and analysis of cohort studies. Lyon: International Agency for Research on Cancer, 1987.

101 DerSimonian R, Laird N. Meta-analysis in clinical trials. Control Clin Trials 1986;7:177-88.

102 Sharp S, Sterne J. Meta-analysis. Stata Technical Bulletin Reprints 1997;7:100-6.

\section{Occupational and Environmental Medicine - http://www.occenvmed.com}

Visitors to the world wide web can now access Occupational and Environmental Medicine either through the BMJ Publishing Group's home page (http://www.bmjpg.com) or directly by using its individual URL (http://www.occenvmed.com). There they will find the following:

- Current contents list for the journal

- Contents lists of previous issues

- Members of the editorial board

- Subscribers' information

- Instructions for authors

- Details of reprint services.

A hotlink gives access to:

- BMJ Publishing Group home page

- British Medical Association website

- Online books catalogue

- BMJ Publishing Group books.

The web site is at a preliminary stage and there are plans to develop it into a more sophisticated site. Suggestions from visitors about features they would like to see are welcomed. They can be left via the opening page of the BMJ Publishing Group site or, alternatively, via the journal page, through "about this site". 